\title{
Enacting Power Asymmetries in Reported Exchanges in the Narratives of Former Slaves
}

Dorien Van De Mieroop (University of Leuven) and Jonathan Clifton (University of Valenciennes)

\begin{abstract}
Direct reported speech has been described as serving many functions in stories, such as increasing vividness, creating authenticity and enhancing audience involvement. Drawing on Bamberg's model of positioning (1997a; 1997b; 2003) and focusing on reported exchanges, we argue that through its 'constructed sequentiality' and its use of discourse strategies, direct reported speech also enacts power relations as they are constructed between the story characters in the referential world. This, of course, has implications for the function of these reported exchanges in the interview world and the construction of the interviewee's moral position in relation to the local and global context. In particular we focus on reported exchanges in narratives about slavery. First, we discuss fragments in which hegemonic power asymmetries between protagonists in stories are talked into being. Second, we focus on a lengthy story in which a slave is constructed as the powerful interlocutor whose discursive rights surpass those typical of his social category. As such, the non-essentialist nature of this discursive construction of power within the referential world is foregrounded and it is also demonstrated that reported exchanges can have many diverse functions within the interview setting.
\end{abstract}




\section{INTRODUCTION}

Reporting the talk of others is an important aspect of the human communication process, since it is essential for interlocutors to refer to what others have said in order to link up with the words, positions and opinions of others. It is thus not surprising that many studies have been devoted to the analyses of the forms and functions of reported speech (for an overview, see Holt, 1996, p.221; Clift \& Holt, 2007) and of their enquoting devices (see e.g Mathis \& Yule, 1994; Fox Tree \& Tomlinson, 2008). Although research has demonstrated that there are many categories of reported speech to be distinguished, including the presentation of speech versus thought, and that the boundaries between these categories are often clinal rather than distinct in nature (see e.g. Semino, Short \& Culpeper, 1997), it suffices for this study to point at the distinction between direct and indirect reported speech because of our functional rather than formal approach. This distinction is related to four essential differences in English, namely concerning the addition of the subordinating conjunction that and the adjustment of verb tenses, pronouns and other deictic markers (cf Banfield, 1973, p.3). In particular, we focus on reported exchanges, consisting of sequences of direct reported speech and we aim to contribute to exploring its functions, more particularly in storytelling which has been described as "the major (but not the only) environment for reported speech" (Haakana, 2007, p.150). More specifically, using data drawn from interviews with former slaves that were recorded in the 1930s, we aim to demonstrate how power relations are enacted in the storyworld by the positioning of the protagonists through the use of reported speech. On the one hand, we look at how access to discursive resources in reported exchanges is distributed among the protagonists and on the other hand we investigate how this reflexively situates the protagonists within wider discourses (master narratives) which legitimize, or challenge, social relations and differences of power inherent in the ante-bellum plantation system. In order to tackle these issues, we first go into a discussion of the central themes and concepts that are 
used in our article, namely reported speech, positioning, conceptions of power and context, before discussing the data we are using.

\section{REPORTED SPEECH}

On the one hand, using direct reported speech implies "reduced personal responsibility" (Goffman, 1979) for the speaker, since his/her role is constructed as being limited to that of animator or "sounding box", instead of also being "author" and "principal" of the utterance (Goffman, 1979, p.17). Such a shift in footing, which gives the utterance "an air of objectivity" (Holt, 1996, p.230), can be used strategically, as has for example been described in media-interviews (Clayman, 1992; 2007) and in the context of mediums who 'report' the words of the dead (Wooffit, 2007). Particularly in narratives, direct reported talk "adds a tone of authenticity and veracity" (Schiffrin, 2003, p.549) since it suggests giving "recipients 'direct access' to an event" (Stokoe \& Edwards, 2007, p.339) of which the narrator seems to have been a first-hand witness, even if the surrounding context suggests the opposite (Norrick, 2003, p.67). Furthermore, the use of direct reported speech not only adds "verisimilitude to the narrated event" (Moita-Lopes, 2006, p.301), but it is also a performance device that keys "the stories as replayings of the events narrated, and not as simple reports" (Georgakopoulou, 1995, p.464). This also helps listeners to identify themselves with the protagonists (De Fina, 2006, p.372) and it adds vividness to the story (Wooffit, 2007, p.267). As such, by dramatizing the events, direct reported speech is a powerful way of "showing", rather than "telling" the audience what happened (Buttny \& Williams, 2000, p.122) and thus it is not surprising that it often occurs at the climax of the narrative (see e.g. Drew, 1998; Holt, 2000) and that it is found to be repeated almost verbatim in retold tales (Norrick, 1998, p.91). 
On the other hand however, as Tannen's use of the term "constructed dialogue" (Tannen, 1989) instead of direct reported speech suggests, this 'reporting' of others' words should be regarded as a transformation (Bakhtin, 1981) rather than an exact rendition of the original words as they were uttered by, in Goffman's (1979) terms, the "author". Comparisons of the original wordings and the subsequent direct reported speech clearly indicate that these diverge quite significantly, although they often capture "the spirit" of the original (Buttny \& Williams, 2000, p.121). And even if the 'original' words are literally repeated, the new context in which they are uttered when they are being reported causes a fundamental change in their discursive functions (Tannen, 1989, p.112).

So from an interlocutors' perspective, one of the fundamental functions of direct reported speech is the creation of a suggestion of accuracy and evidentiality. From a researchers' perspective however, this authenticity claim is bracketed, not only because it has been demonstrated to be inaccurate, but also because, as Vološinov (1973, p.119) points out, the dynamic relationship between the speech being reported and the speech doing the reporting must be taken into account which thus draws attention to what the direct reported speech is actually doing in its new, discursive context. So far, many studies have focused on the functions of direct reported speech within their sequential contexts (see e.g. Buttny \& Williams, 2000; Holt, 2000; Stokoe \& Edwards, 2007; Wooffit, 2007). In particular, some studies have explored the link between reported speech and power or inequality (see e.g. Bauman \& Briggs, 1992; Álvarez-Cáccamo, 1996; Buttny, 1997; Buttny \& Cohen, 2007). These studies have shown that reported speech is "not a neutral, disinterested activity", but rather that speech is reported "along with assessing or evaluating it" (Buttny, 1997, p.484), as such constructing an either aligning or challenging position for the speaker vis-à-vis the power asymmetries that are talked into being through reported speech. Often, the assessments of such reported speech utterances are explicitly voiced, but they can also be implicitly 
conveyed, for example "through the exaggerated prosody or voice quality of the reported speaker" (Buttny, 1997, p.501) or through code choices related to linguistic ideologies (Álvarez-Cáccamo, 1996). We aim to add to this body of research by focusing on the interplay between reported speech and its local and global contexts in an era in which power inequality was strongly embedded in society, as explained below. We operationalize this by using the concept of 'positioning'.

\section{POSITIONING}

Our approach to investigating the relation between reported speech and power is to focus solely on reported exchanges in narratives, by which the narrator thus constructs a sequential format for the reported speech utterances (Buttny, 1997, p.491). In order to analyse the way in which reported speech in narrative telling does identity work that enacts power relations at a micro conversational level and macro socio-political level, we think it is particularly useful to draw on Bamberg's model of positioning (Bamberg, 1997b; Bamberg, 2003), which consists of three levels that are strongly interrelated, as Bamberg explains:

"By positioning the characters at the content plane with regard to one another, the speaker positions him/herself with regard to the listener; and this process works simultaneously the other way around. The coordination between these two planes results in the establishment of a moral position for which the speaker can be held accountable, irrespective of whether the speaker him/herself plays a role in what is being talked about, or whether the talk is merely about others." (Bamberg, 1997a, p.335) 
So in this article, we start by zooming in on the way reported exchanges are used at the first level of positioning. On this level, the way characters in the referential world are positioned in relation to one another is central and we operationalize this by looking specifically at the way the narrator voices his or her characters' utterances and constructs their interactions with one another through the use of reported speech. Of course, this analysis also has implications for the second level of positioning (i.e., the way "the speaker positions him/herself with regard to the listener" (Bamberg, 1997a, p.335)) and the third level of positioning (i.e., "the establishment of a moral position for which the speaker can be held accountable" (Bamberg, 1997a, p.335)). This is because "the way the referential world is put together points to how tellers index their sense of self in the here and now" (Bamberg, De Fina \& Schiffrin, 2011, p.186). In this article, we will particularly focus on the link between the specific format of the reported exchange between the characters at the content plane and its function in the interviewing context, thus exploring the link between the first two levels of positioning, while also paying attention to the third level in which the speaker constructs a moral position which can be related to its local and global context.

In particular, in our analysis of reported exchanges in the referential world we focus on how the narrator distributes discursive rights to the characters in the storyworld and how as such power asymmetries are enacted $\left(1^{\text {st }}\right.$ level of positioning) and consequently 'shown' to the listener in the interview world ( $2^{\text {nd }}$ level of positioning), which entails the construction of a position in relation to the social norms ( $3^{\text {rd }}$ level of positioning). For this, we study (1) the way power is performed by the narrator through reported speech sequences at a micro level and how this enactment acquiesces to, or alternatively resists, the hegemonic power relations at the macro level and (2) how this functions at the local contextual interview level. Thus we now go into a discussion of the concept of power, after which relevant contextual information is provided. 


\section{CONCEPTIONS OF POWER}

Whilst power in its simplest form can be conceived of as the capacity of an individual to constrain the actions of another, according to Lukes (1974), the most important and insidious from of power is domination - the so-called third dimension of power. It is the:

"exercise of power to prevent people, to whatever degree, from having grievances by shaping their perceptions, cognitions and preferences in such a way that they accept their role in the existing order of things, either because they can see or imagine no alternative to it, or because they see it as natural and unchangeable, or because they value it as divinely ordained and beneficial" (Lukes, 1974, p.24)

In others words, it is an ideological form of power that exists when people are subject, or acquiesce, to domination either by coming to believe in the values that oppress them or by being resigned to the existence of such domination (Dowding, 2006). This clearly builds on Gramsci's (1971) notion of hegemony whereby the dominant group seeks to project their own way of seeing the world onto the dominated group so that they accept this particular world view (or reality) as 'natural'. Fairclough (1989), speaking from a discursive perspective, argues that power is closely linked to such ideologically-driven concepts of domination since language conventions "are a means of legitimising existing social relations and differences of power, simply through the recurrence of ordinary, familiar ways of behaving which take these relations of power differences for granted" (Fairclough, 1989, p.2). Thus power works through the flow of peoples' knowledge about what they can, or cannot, say or do in certain situations. Moreover, it is through the naturalisation of such interactional routines that social relations, enacted in discourse, are constrained or enabled. Consequently, such a flow of knowledge, as discursive practice, exercises power since, as Jäger (2001) observes, it 
determines the collective doing and/or formative action that shapes social reality in which the subjects act and so position themselves relative to each other within this reality which, taking a constructionist approach, is "not 'real' beyond the social practices that construct and maintain it as such" (Benwell \& Stokoe, 2006, p.12). The corollary of this is that in the discursive construction of these 'realities', social actors come to accept or resist subject positions which are "essentially a matter of doing (or not doing) certain things" (Fairclough, 1989, p.38) and thus enact power relations. Discourse then is inextricably and reflexively linked with the doing of power, and as Flores Farfán and Holzscheiter (2010, p.139) argue, "power constitutes and reproduces discourse, while at the same time being shaped and reshaped by discourse itself".

Further, Fairclough (1989, p.43) argues that power is enacted in two ways: either by the most powerful participants controlling what can be said and how this can be said (power in discourse) or by the most powerful participants controlling the master narratives available to social actors (power behind discourse). Firstly, as concerns power in discourse, for the purposes of this paper, we draw on the notion of power as it is used in studies based on real time interaction and so following Hutchby and Wooffitt (1998, p.170), we conceptualise power as "the structurally provided ability to constrain the actions of others". Furthermore, from this perspective, power is not seen as the playing out of pre-discursive social roles with fixed discursive rights, but rather a social constructionist perspective is taken which views power as "enacted through performance" (Baxter, 2009, p.22, italics in the original) in a reality that is constructed and enacted simultaneously with the creation of the text (Muntigl, 2004a, p.112). Power is thus constructed by the way social relationships are enacted in language, since "[i]t is through language that interactants enter into exchanges in which propositions and proposals, attitude, status and involvement are negotiated" (Muntigl, 2004b, p.56). Many researchers have already pointed to the importance of analysing the sequentiality 
of turns within an interaction as indexical of the enactment of power relations (see, for example, Hutchby, 1996; Hutchby, 1999; Kitzinger, 2000). We aim to apply these insights to the study of reported exchanges here. So we study the 'constructed sequentiality' of reported exchanges as an indexical marker of the power relations that the speaker is constructing between the story world-characters at the first level of positioning. From this perspective, the distribution of the characters' discursive rights that is constructed through the sequential properties of reported speech is crucial for their allocation to specific social categories. As Matoesian (1993, p.104) points out, such identity work involves power since it constrains, or allows, access to discursive resources through which participants influence the field of social action available to each other. It is therefore interesting to examine the reflexive relationship between access to discursive resources and identity as regards the positioning of protagonists in the referential world in relation to each others' identity. Or, as Bamberg (2010, p.6) states, protagonists are positioned in relation to the way in which "others are 'brought to existence' (constructed) in terms of social categories" and this positioning necessarily indexes the enactment of relationships of power. Furthermore, at this micro level, we intend to complement this analysis of the constructed sequentiality of reported exchanges by investigating the particular discourse strategies in direct reported speech that reflect power relations, like for instance the way face threatening acts (Brown \& Levinson, 1987) are negotiated in the constructed dialogues, for example by the use of hedges or epistemic modal verbs (see e.g. Holmes, Stubbe \& Vine, 1999). As Flores Farfán and Holszcheiter (2010, p.145) point out, politeness is linked to the enactment of power since identities can be maintained to allow for the normal flow of conversation whilst limiting direct power confrontations. Thus by analyzing the particular way in which the narrators sequentially construct dialogues, formulate these constructed turns and give or deny the protagonists of their stories discursive rights, we have a window, not into the power relations that 'existed' in 
the past, but into the performance of power relations as the interviewees construct this through positioning characters vis à vis one another in the referential world, as such constructing a moral position for oneself.

Second, as previously noted, Fairclough draws our attention to power behind discourse which he (1989, p.55ff) conceptualises as the way in which conventions, or knowledge, which shape the talk of social actors are mediated through ideologies which render such conventions natural and so, potentially at least, unchallenged. Moreover, by naturalising the interactional routines that constrain social relationships enacted in talk, such ideologies necessarily position and constitute the subject and so enact power. More specifically, in terms of narrative analyses, power behind discourse equates to the master narratives that participants may relate to in different ways: they may "adopt, resist and offer subject positions that are made available to them in master narratives or discourses" (Benwell \& Stokoe, 2006, p.42). Thus, for example, Litosseliti (2006) notes that discourses can be drawn upon to represent and maintain gendered social practices so that by accessing the discourse of "women as emotional beings' asymmetrical positions for men and women are normalised and this has the effect of facilitating the marginalisation of women in politics for example. Finally, we also study how discursive struggles over power behind discourses are reported by the narrator and how the power enactment that is locally constructed through these reported exchanges can be related to the hegemonic power relations of the global context at a macro level, or how it "might contribute to changing these macro-structures" (Wodak, 2009, p.36) by assuming a moral position that resists these master discourses. Moreover, we investigate how the relations between the micro and the macro level that are constructed through reported exchanges function, and are interactively co-constructed in their new, local discursive interviewing contexts. 


\section{CONTEXT}

Of course, studying discourses in their contexts is quite a complex endeavour (see e.g. discussion in Wodak \& Weiss, 2005, p.127-128), especially since contexts "are not 'objective' (dimensions of) social situations [...] that cause or determine (properties) of discourse", but rather they are subjective, dynamic and always individually different (Van Dijk, 2009, p.248-249). Nevertheless, it remains important to make some general observations about the contexts of the data of our article - both local and global - so that general background information is provided for the reader on the one hand, and so that the analytical findings can be related to these contexts on the other hand.

First of all, regarding the local context, we selected a dataset that consists of interviews. The stories that are typically elicited in interviews have been called "big story" narratives (see e.g Bamberg, 2006; Freeman, 2006; Georgakopoulou, 2006) and we decided to work on these because such narratives are more prone to contain lengthy reported exchanges than "small story" narratives because of the typical extensive floor holding rights for the interviewees. This local interview context in itself is of course a well-known example of "the exercise of power", since "the structure of the whole interaction is defined by a hierarchical stratification" (Flores Farfán \& Holzscheiter, 2010, p.148) in which the interviewer's dominant voice strongly contributes to the process of meaning making (Holstein \& Gubrium, 2003). So this has to be taken into account as well when looking at the way these reported exchanges function at the second level of positioning. Many researchers have argued in favour of taking such an interactional approach to interview data (see e.g. De Fina, 2009) and many studies have already pointed to the influence of the interviewer in the construction and negotiation of meaning in interviews (see e.g De Fina, 2011; Van De Mieroop \& Clifton, 2012). 
Secondly, we selected a dataset that is ideally suited for this research question because of its close relation to issues of power on a global contextual level, namely slave narratives. We studied a collection of interviews with people who were born into slavery (between 1823 and the early 1860s) and who were interviewed about their lives as slaves almost sixty years after the American Civil War. From the late 1920s onwards, significant efforts were made to collect slave narratives, of which the WPA-project ${ }^{\mathrm{i}}$, consisting of over 2,000 first-person accounts of slavery (Yetman, 1967), was by far the largest. These interviews not only look back at a time characterized by severe power asymmetries, but the interviews themselves also have to be situated in a socio-political context of institutionalized racial inequality enforced by the Jim Crow laws, which "dominated social life as pervasively and almost as harshly as slavery ever had" (Escott, 1991, p.42). Due to the extent of the corpora of slave narratives, there is a lot of variation in how these relate to, and function within, their contexts, as is for example shown by Whooley (2006). While some interviews are characterized by the black interviewees giving short, routine answers to the often patronizing, or sometimes even condescending questions of the white interviewers (Vann Woodward, 1991, p.51), efforts were made in other interviews to overcome this blatantly asymmetrical situation. For example, Alan Lomax worked with black colleagues who carried out the interviews since, as he observes, "it was clear the Southern blacks would not readily confide in a white folklorist" at that time (Lomax, 1993, p.xii). But even when working with black interviewers, power asymmetries are still prevalent in these interviews - as in most interviews for that matter (cf Flores Farfán \& Holzscheiter, 2010, p.148-149) - and many of the slave narratives have been criticized for the questionable insight that they have to offer into what slave life 'really' looked like from a historical perspective (Vann Woodward, 1991). However, since from a linguistic perspective, narratives are generally considered not to provide "a clear route into 'the truth"” (Atkinson \& Delamont, 2006, p.166), our interest is not in what did, or did not, 
happen in the past. Rather, we are interested in how the story is constructed and negotiated during the interview, and thus we look at how elements from the global contextual level are made relevant locally through the use of reported exchanges and how this relates to issues of power.

\section{DATA}

Rather than being audio-recorded, many of the slave narratives were only transcribed by hand (Soapes, 1977, p.33) and so many of the existing transcripts are in fact distorted versions of the actual interviews and alterations occurred regarding the interview's content (Blassingame, 1975, p.485) and language (Blassingame, 1975, p.486). For the purpose of this study and so that we could get a detailed insight into the way the interviewees performed the constructed dialogues under study here, accurate transcriptions and access to audio recordings is of course vital. Fortunately, from a number of collections of slave narratives, a small selection of twenty-three interviews was conserved on discs at the American Folklife Center's Archive of Folk Culture at the Library of Congress. These are now publicly available on the internet in the 'Voices from the days of slavery'-collection (Library of Congress, 2011), which contains almost seven hours of recorded interviews and their transcriptions. In order to represent the way the interviews were voiced in more nuanced ways, we refined these transcriptions and added conversation analytic transcription symbols (Jefferson, 2004). In this respect, we paid special attention to prosody and speaking volume and speed on the one hand, but on the other hand, we also decided to use the standard English orthography throughout the transcripts even though the speech was characterized by a number of dialectal features. We made this decision because we did not see any patterns in the distribution of these features typical of specific language variants that could be related to our research focus, as was for example the case in Álvarez-Cáccamo’s study (1996). ${ }^{\text {ii }}$ 
In previous studies, we already focused on these data by studying the way animal comparisons function in these stories (Van De Mieroop \& Clifton, 2011) and how the relevance of ethnicity is interactively negotiated between the interlocutors (Van De Mieroop \& Clifton, 2012). The fragments we selected for this study come from three interviews, of which a brief overview is given in table 1 .

\title{
*** INSERT TABLE 1 ABOUT HERE***
}

\begin{abstract}
ANALYSIS
We discuss a number of fragments from these three interviews in which reported exchanges are constructed. In particular, we look at the way in which these constructed dialogues are inserted into the narrative and how they contribute to the point that is being made. The analysis is divided in two sections: the first section contains a number of fragments that can be considered to be typical examples of direct reported speech sequences in the slave narratives which enact the hegemonic power relations of the slave system. The second section presents a lengthy story from one interview in which quite a different picture of the quoted characters' turn distribution and orientation to face wants emerges, thus providing an enactment of power that seems to challenge the hegemonic power relations in a society based on slavery. In both sections, and in order to provide an integrated picture of the functions of these constructed dialogues within their contexts, the analysis of the direct reported speech is embedded in the analysis of the immediately surrounding text.
\end{abstract}




\section{PERFORMING HEGEMONIC POWER DIFFERENCES BETWEEN MASTER AND}

\section{SLAVE}

We start our discussion with an extract that represents a typical sequence of direct reported speech as it is regularly inserted in the stories that the interviewees are relating and which enacts master/slave power relations. This extract comes from a discussion regarding the slaves' field and house work which is initiated by the interviewer in lines 40-41:

Extract 1 - part 1 (McDonald; IE 1: unidentified woman, IE 2: McDonald)

40 IR Well did you work in the field or you work

$41 \quad$ in the house?

42 IE1 I work in the field and the house $\uparrow$ too. Both places.

$43 \quad($.

44 IE1 But I like the field the $\uparrow$ best.

45 IR Uh huh. (.) Why did you like the field the best, best?

46 IE 1 Well just because I catch more good bree:ze

47 and more good (.) fresh air out in the field

48 than I does in the kitchen, uh, in the house.

49 Now you know that.

50 IE2 I didn't go the field till I was 19 yea[rs old.

51 IE1 [I know the field.

52 IE2 I, I went to the field when I was 19 years old.

53 I remember the old boss says 'Well Joe' 
After the interviewer introduces this topic, it is first briefly discussed by the female interviewee, who states her preference for work in the field (line 44). This is then probed for further by the interviewer (line 45), after which the female interviewee accounts for her preference by painting a positive picture of the work in the field, relating it to good bree:ze and more good (.) fresh air (lines 46-47). She ends her turn with an other-selection (line 49), which is oriented to the other interviewee, Joe McDonald, as can be derived from the context. The latter starts his turn by voicing an orientation to a story (Labov \& Waletzky, 1966) ${ }^{\mathrm{iii}}$, but this is overlapped by the first interviewee (line 51) who expresses her expert status regarding the work in the field. After this overlap, the second interviewee (line 52) gains the floor for an extended turn and repeats the orientation phase of his story. Then he inserts the first turn of a reported exchange (line 53), but immediately introduces a side-sequence which discusses his first name in relation to that of other people with similar names (5 lines omitted of IE2's turn). Then from line 59 onwards, the reported exchange as already initiated in line 53 , is taken up again:

Extract 1 - part 2 (McDonald; IE 1: unidentified woman, IE 2: McDonald)

59 IE2 And they put me (to) plo:wing, you know. (.)

$60 \quad$ Says, '个Joe.' Says, 'Sir.' 'I want you

61 to go up yonder < while the baby's asleep $>$ and plow.'

$62 \quad>$ Say, 'When Misses $\left(\left(\right.\right.$ name $\left.\left.^{\mathrm{iv}}\right)\right)$ call, you go back to the house

63 and see if the baby stir.' Baby went to sleep,

64 you know, slept two or three hour and

65 I plowed $\uparrow$ till the old boss got $\downarrow$ back $<=$

66 IR $=(($ short laugh $))=$ 
67 IE2 =But I didn't 个like the [field, didn't go the field till I was 19.

68 IE1 $\quad\left[{ }^{\circ}\right.$ I love the field ${ }^{\circ}$

69 IE2@@@ Didn't go the field till I was 19.

70 IR What kind of work did you like best in the field?

The interviewee starts his story with an introductory sentence containing the story abstract. The formulation of the sentence already foregrounds the interviewee's passive role in the decision where he would be working, since in spite of his role as active agent of the plowing activity, the interviewee is put in the position of direct object (line 59: they put me) while the slave owners (they) are the agents of this decision. This already contrasts strongly with the agentive tone of the female interviewee's story in the first part of this extract. The story then consists of a reported exchange which starts with the slave owner explicitly addressing the interviewee by the first name, after which the latter responds by addressing the former by means of the formal term of address Sir (line 60). These forms of address quite explicitly enact the asymmetrical power relation between the categories slave and master, which are thus implicitly invoked. This power difference is also performed in the rest of the dialogue, which consists of two turns by the slave owner. These contain an expression of obligation that explicitly foregrounds the master as the agent of the command (lines 60-61: I want you to...) and two peremptory declaratives (lines 62-63). Both result in a highly instructive tone which signals the master's powerful position. After this constructed dialogue, the interviewee quite factually narrates the complicating action of this story in which he describes that while the baby slept, he worked in the field. The latter statement foregrounds the interviewee as the agent of the work (line 65) and is treated as a laughable by the interviewer, probably because of the marked prosody and the reference to the slave owner as the old boss in line 65 . As an evaluation of this story, the interviewee adds a statement which is constructed as contrasting 
with the story of the other interviewee, as the introductory conjunction but and the marked rising intonation of the verb like indicate. Furthermore, it highlights that in spite of his dislike of field work, the interviewee was working in the field after all, although he may have been able to postpone it. This is suggested by the interviewee in the repeated utterance didn't go the field till I was 19. Initially (line 50), this can be read as a negative response to the interviewer's question and its positively formulated variant (line 52) as an orientation to the story, but at the end of the story (lines 67 and 69) it can serve two functions: it can either indicate that the slave had an influence on the division of labour after all since he was able to postpone it till he had a certain age, or it can function as a mere repetition of the initial negative response, as such giving up his extended storytelling floor holding rights and picking up the interactional thread again. The latter interpretation is supported by the fact that the interviewer self-selects again in line 70 and furthers the interaction by asking a follow-up question.

So the second interviewee's preference for a particular type of work as probed for by the interviewer, is constructed as irrelevant in this story since the interviewee had to do both types of work anyway, even though he may have been able to postpone work in the field. The slave's relatively small influence in this matter puts him in a powerless position and this message is also conveyed by means of the reported exchange which hardly gives the slave a voice and highlights the powerful position of the slave owner. As such, at the second level of positioning, the interviewee's story implicitly refutes the other interviewee's answer, as also becomes clear from the explicit confrontation between the differing opinions of both interviewees at the end of the fragment (lines 67-69). Apart from countering the other interviewee's story, the reported exchange also makes relevant the categories master and slave through the initial use of terms of address and through the asymmetrical distribution of discursive rights as voiced by the interviewee (i.e. the master's right to give orders). As such, 
this direct reported speech sequence enacts the hegemonic power relations present in the antebellum slave states at the first level of positioning and it refutes the other interviewee's contribution of which the positive, agentive tone implicitly qualified slave work as enjoyable and slaves as entitled to having likes and dislikes at the second level of positioning. As such, this interviewee constructs an implicitly critical position which not only refutes the romanticized image the other interviewee is sketching of a slave's work, but it also counters the relevance of a slave's preference as implied in the interviewer's question. The interviewee thus implicitly highlights a typical feature of power asymmetry, namely that he did not dispose of "the possibility of having one's own will within a social relationship against the will or interests of others" (Reisigl \& Wodak, 2009, p.88).

In the majority of the dialogues in these interviews, the slave owners are constructed as having first turn rights and so they are typically the initiators of topics. Such access to first turns is often considered to be a major way of taking interactional control since it constrains what can be said in a second turn and it gives the first speaker the potential to take the third slot in a sequence so as to retain interactional control (ten Have, 1991). The following fragment is a rare example of an exception to this rule since it contains a first turn that is not uttered by the master, but by a slave. In this extract, the interviewee, Billy McCrea, is talking about the end of the Civil War and the departure of the Yankees (referred to as them) in line 378. This extract occurs almost in the middle of a lengthy turn by the interviewee which was formulated as an answer to the interviewer's question in lines 312-313 and 316-318 (What do you remember about the, when slavery was over? and Well you said you, they all kept going, tell me about them coming through here with cannons.) These questions probed for a general story about the end of the Civil War and this was also delivered by the interviewee by means of an extensive turn consisting of almost 1,300 words (approximately 130 lines). This story occurs 60 lines after the interviewee started his response. 
Extract 2 (McCrea, turn by the interviewee)

378 We a::1l would standing looking at them, all going home.

379 And I said, I ask them, I said, (I ask them), I say,

380 '个Mama, where they, where they going?'

381 Said, 'They a:1l going home now.'

382 And old Colonel ((name)), that was our master, he was in there,

383 and he say, '个Well, 个Harriet, all of you niggas is all free now.

384 Yankees all going home.' I remember that just as ${ }^{\circ}$ we:11 ${ }^{\circ}$. (.)

385 Right, right in town where we living at.

386 Right above the new (.), the new, u::h, 个Post Office.

In this story, the interviewee first briefly describes the scene in line 378 and stresses the collectivity of the two groups (slaves and Yankees) by means of the emphasizing all that is added to both groups (we and them). Then the interviewee shifts to a personal footing and presents himself as the agent of the quotative verb. Interestingly, after the initial I said, this quotative is reformulated four times and in these reformulations the addressee of the forthcoming utterance is negotiated: from unspecified (I said $(2 \mathrm{x})$ ) to addressing the Yankees (I ask them $(2 \mathrm{x})$ ) and then back to unspecified again (I say). The vocative in the direct quote itself (line 380: TMama) however, immediately clarifies that the addressee of the interviewee's question is his mother, whose response is also given in direct reported speech in the following line (line 381). This short question-answer sequence is quite exceptional in this corpus because the question is initiated by a slave. However, through the vocative in the beginning of the question in line 380 , the interaction is immediately characterized as talk 
among slaves. Importantly, through an and-prefaced, and thus relevant and coherent continuation (cf Heritage \& Sorjonen, 1994; Neville, 2006), the slave owner is then introduced to the scene by means of a referential disambiguation (that was our master) and an orientational reference (he was in there) in line 382, after which his contribution to the reported exchange is formulated. Because of the vocative (line 383: Harriet) and the response marker well that reflects the speaker's awareness of the need to build coherence (Schiffrin, 1987, p.126), this utterance in direct reported speech can be read as constructing a topically related turn. In this case, the slave owner makes a crucial statement (line 383: all of you niggas is all free now) which is an epistemic upgrade since it shows that he has superior knowledge (Stivers, 2005). In particular, the slave owner demonstrates his insight into the implications of the slaves' observation that the Yankees are leaving, thus displaying his knowledge about the outcome of the Civil War and the consequent end of slavery. Then he repeats the previous slave's answer (line 384), as such implicitly ratifying the correctness of her contribution to the interaction and thus enacting his discursive rights to modify, correct or ratify his slaves' contributions. ${ }^{\mathrm{v}}$

The interviewee then concludes this story by means of a number of veracity claims, on the one hand regarding his own epistemic access to the narrated events through his memories (line 384), on the other hand regarding the details of the particular place in which these events occurred (lines 385-386), which are characterized by a shift to the contemporary time frame (line 385: town where we living at; line 386: the new (.), the new, $u:$ h, 个Post Office) that enhances the verifiability of the story. So even though the slave initiates the question in this fragment, which is highly unusual regarding the typical distribution of discursive rights to the incumbents of the categories master and slave in the data, he is not constructed as a powerful interlocutor, since the question is constructed as oriented to another slave. In the end, it is still the slave owner who is presented as having strong discursive rights. So even in this extract, 
the construction of hegemonic asymmetrical power relations through direct reported speech sequences is not violated at the first level of positioning and at the second level of positioning, the reported exchange functions, together with the veracity claims in lines $358-386$, to add verisimilitude to the story, which the interviewer had already qualified as a remembrance, and thus prone to forgetting. As such, he positions himself as somebody who testifies to what happened, without really assuming a clear position in favour or against the slave system, but rather strengthening his claim to veracity.

The final fragment of this section occurs right at the beginning of the interview with Joe Mc Donald and the question was not captured on disc, but as the interviewee's answer indicates, it possibly probed for the interviewee's upbringing and work as a young slave. In line 3 , the interviewee uses a vague pronominal reference to the slave owner $(\mathrm{him})$ in whose house he used to live, and after a disambiguating probe by the interviewer (line 4), the interviewee continues his turn and starts discussing his upbringing in line 5:

Extract 3 (McDonald, IE: McDonald, IR: Ruby T. Lomax)

1 IE Yeah.

2 IR All right.

3 IE Yeah. I was rai:se in the house with him.

4 IR Mister [F. M.

5 IE [Mister F. M., and uh, they taught me mighty good,

6 they teach me good. They said, I remember,

7 says, 'Joe?' I say, '

$8<$ 'When we are dead and in heaven,'> (.) they said,

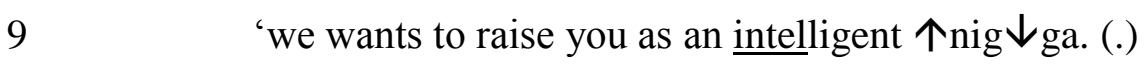


We wants you to have good friends like we have got.'

11 >Say, 'You'll never be scratched by good rich, sensible white folks $<$.h because they can tell who you are by your rai:sing and your compliments. That show that <you been rai::sed>,' (.) he said (.) ' $\downarrow \underline{\text { not }}$ by the $\uparrow$ colored (.) $\downarrow \underline{\text { but }}$ by the $\uparrow w h i t e . '$ I wa:shed and ironed. Some days I'd wash a hundred pieces. Some, e:very morning I'd have five beds to make up, five fires to mix, and the childrens to dress and churning to do.

In line 5, the interviewee introduces the discussion of his upbringing with an anticipatory positive evaluation, which is first boosted (mighty good, line 5) and then repeated in a more neutral way (good, line 6). This explicitly aligns the interviewee with the hegemonic way of bringing up slaves in the ante-bellum period and constructs a moral position of acquiescence to this system. This is further supported by the fact that the initial singular reference to the slave owner (him, line 3) is replaced by a vague third person plural pronominal reference (they) which is consistently used in lines 8-13 and which invokes a more general perspective on slave owners than a singular reference would have done.

Again, the main part of the fragment is voiced by means of a direct reported speech sequence, of which the beginning mirrors the sequence in extract $1-$ part 2 , thus also illustrating first turn rights for the slave owner and hierarchically marked differential terms of address for the slave versus the slave owner (line 7). Furthermore, also the marked difference in speaking volume (loud for the slave owner and silent for the slave) contributes to enacting the hegemonic power difference between the interlocutors of the reported speech sequence. 
Then, the interviewee continues with a long reported turn by the slave owner which is only interrupted by quotatives (in lines 8,11 and 14). Interestingly, this long quote talks into being a world view in which a black man can only be raised into being intelligent (line 9) and into having the right kind of friends (line 10) and this only on the condition that this upbringing is in the hands of white people (line 15). The latter reasoning is very explicitly formulated by means of a prosodically marked contrasting parallel formulation juxtaposing the colored and the white (line 15), thus talking into being the relevance of ethnicity, and the inherent discourse of the civilising nature of white supremacy vis-à-vis the inferior Negro, as a decisive factor in the success of a slave's upbringing. Crucially, this is presented in a benevolent way, since it is initially framed as a concern for the slave's future after the death of the slave owners (line 8) and as protection of the slave against being hurt, at least by white people who are said to be able to judge people on the basis of their upbringing (lines 11-13). These whites are very positively qualified by means of an enumeration of positive adjectives (good, rich, sensible, lines 11-12), thus clearly highlighting their superiority. As such, the master narrative of white supremacy is talked into being and since the interviewee then simply continues by uncritically listing his daily tasks (from line 16 onwards), no counter to this master narrative is provided. This lack of a counter, together with the positive anticipatory evaluation of this upbringing in lines 5-6, shows the interviewee's unchallenging alignment with the hegemonic power difference between master and slave and as such legitimizes the slave system by framing it as benevolent to the dominated, thus acquiescing to the white supremacy ideology.

So by these reported exchanges in which the typical differential discursive rights of slaves and masters are enacted, the interviewees on the one hand seemingly offer a window into how these interactions took place, thus making a bid for verisimilitude. On the other hand, they at the same time construct a position for themselves in relation to the local, 
interviewing context, for example by refuting the relevance of the interviewer's question (cf extract 1) and in relation to the global context of racial inequality. This position may range from ratifying to being implicitly critical of this system, as respectively fragments 3 and 1 demonstrated. Crucially, these fragments come from the same interview, thus illustrating the versatility of an interviewee's positionings in relation to the interactional and global contexts.

\section{ENACTING NON-HEGEMONIC POWER DIFFERENCES}

Although they are very rare, there are also fragments of direct reported speech in which the discursive rights of the slaves are constructed quite differently. The story we discuss here comes from the interview with George Johnson, who speaks quite positively about slavery throughout the interview and who frequently presents himself as an admirer of his former slave master, Jefferson Davis (see Van De Mieroop \& Clifton, 2012). The latter was quite an emblematic figure, since he was the leader of the Southerners in the Civil War. During the interview, the interviewer pursues the topic of Jefferson Davis further by explicitly probing for a particular story that both the interviewer and the interviewee are clearly familiar with (lines 167-169). This story is quite lengthy (over 500 words) and its embedded stories nicely follow the structure as laid out by Labov and Waletzky (1966). Given its length, it will be presented in three separate extracts which follow each another. In the initial part, the interviewee immediately starts with the orientation phase of the first part of the story. This is not surprising, since the interviewer has already provided the abstract of the main part of this story in the question and thus the interviewee can immediately start with the story itself.

Extract 4 - part 1 (Johnson)

167 IR You, tell me how ah, the, how, the story as to how 
169 during the Civil War for him?

170 IE Yeah, well, when, when, when, a:h the Yankee

171 was coming $\uparrow$ South to look after eu- (.) those places down there

172 to rob somebody. Uncle Ben see it. (.)

173 Uncle Ben went to old Miss (.) Miss Irene, his wife,

174 say, >'Well, Miss I'm have to go Richmond.

$175 \quad$ Got to see master Jeff.'<

176 She say, >'What you want to see master Jeff for, Ben?'<

177 Say, 'I got to see him.' Say, >'Can't you see me?'<

178 'No, Miss you can't do no good. I can't, I don't want to see you.

179 I want to see master Jeff. I want a passport.

180 >Send me to Richmond, Virginia, to < see master Jeff.'

181 So they gave Uncle Ben the passport. (.) He went on to Richmond.

The interviewee starts this embedded story by implicitly putting it in the historical frame of the Civil War, as was explicitly voiced in the interviewer's question. He does this by referring to the southbound movement of the Yankees (lines 170-171), who are qualified as thieves, as the verb to rob (line 172) indicates. This negative presentation of the Yankees is then linked to the protagonist of the story (line 172: Uncle Ben), who is introduced as a witness of these events. The embedded story then moves into the complicating action, which consists of a reported exchange between the protagonist and the wife of Jefferson Davis, as implied by means of the use of the third person possessive pronoun his (line 173). In this constructed dialogue, the protagonist is presented as the active agent throughout this embedded story. This is because he takes the initiative (line 174-175) by going first and by devising a plan (going to 
Richmond to see master Jeff). Moreover, when Davis' wife counters this sequentially first with a question asking him to account for his request (line 176), rather than producing a conditionally relevant second which would provide such an account, the slave just states " $I$ got to see him" (line 177), thus almost literally repeating his previous utterance of line 175 . In the same line (line 177), Davis' wife then asks “Can't you see me?”, but whilst this is followed by a conditionally relevant next (line 178: No, Miss you can't do no good.) which provides an account, it is a dispreferred second since it is unhedged and this can be seen as impolite (Heritage, 1984, p.268) and thus threatens the face of Miss Irene and displays insolence and resistance to his hierarchic superior.

Further, the use of the modal verbs in this dialogue is quite telling regarding the way the request is negotiated: it is initially presented by the protagonist as compelling by means of the modal verbs of obligation (line 174: have to, line 175: got to). This modality is then reframed by the wife by means of a modal verb of volition (line 176: want to), but this is resisted by the protagonist who repeats the previous verb of obligation (line 177: got to). The wife then presents herself as an alternative by means of a negatively phrased modal verb of possibility (line 177: Can't you see me). The protagonist responds negatively to this offer, which, as previously discussed, is formulated in quite a face threatening way (Brown \& Levinson, 1987), since the negative response is formulated without being mitigated (line 178: no) and this negative particle is then even boosted by a direct, negative evaluation of the wife's capacities (line 178: you can't do no good). The protagonist then reformulates this modality of impossibility (line 178: I can't) to the modal volition verb want (line 178), which thus foregrounds the slave's own will, which is then emphasized by means of the repetition of this volitional verb (line 179). In the final part of this constructed dialogue, the initial request is negotiated and rephrased as an order, as the imperative send me to Richmond (line 180) indicates. The resolution of this embedded story is that the slave's order is obeyed, as this 
sentence is causally linked to the previous sentence by means of a conclusive conjunction (line 181: so). Thus in this embedded story, the protagonist is never discursively presented as a passive recipient, even though it is actually his hierarchical position as a slave. However, this hierarchical position is talked into being here because the slave's order (send me to Richmond) also constructs the necessity for the slave to gain permission from his mistress to carry out his plan, thus enacting quite a complex power relationship between the two story world characters. One may argue that the slave's position is strengthened in this extract because he is dealing with a woman here, whose position was hierarchically not as high as that of the man, but this explanation is refuted by the way the protagonist is presented in the next part of the story, as discussed below, which follows on uninterruptedly from the previous extract. The story starts again with a new orientation phase, describing the trip Uncle Ben made and it then moves into the complicating action when he arrives in Richmond, Virginia in line 184.

Extract 4 - part 2 (Johnson, turn by the interviewee)

181 He went on to Richmond.

182 Got some bread in his sack and went on to Richmond, Virginia.

183 Got on his ( ) where he went on to Vicksburg.

184 On to Richmond, Virginia, he met master Jeff

185 (an[d he go)

$186 \quad[((I E$ taps his cane three times $))$

187 'Who's that? Come in.' >Walk in there. $<$

188 'Hi there master Jeff.' (2.2) 'He::y, Ben, what you doing here?'

189 Say, 'I come here to see you master Jeff.'

190 Say, 'Ben, sit down and tell me all you kno:w. (.) 
$192>$ 'Everybody all right master Jeff, but something I come

193 to see you a $\downarrow$ bout.'<(.) 'What is it, Ben?' Say,

194 'Master $\uparrow J e f f(2.6)$ those Yankees coming $\downarrow$ South near Vicksburg.

195 They coming down South getting our white folks' $\uparrow$ la: $\downarrow$ nd (1.3)

196 and robbing the nig $\downarrow$ gas. Steal all the $\uparrow m u: l \downarrow$ es. And they in pursuit

197 of Davis' la:nd. I'm tell you what I want you to do.'

198 Say, 'What is it Ben?' (1.5) 'I want you to deed this land to 个ME:. (.)

199 So I'll: have it.' (1.3) He say, 'Ben that won't do no good.'

200 Say, >'Don't you belong to me? The land's mine. You mine.

201 Why, that won't do no good.'< Say, 'Yes, it will do, master Jeff.

202 It will do.' Say, 'How do you 个know?' Say, 'Master

203 Jeff, can't you free me?' Say, 'MY GOD, FREE ME, MAN.'

204 (1.4) Master Jeff held his head down and say, 'Ben you right.'

205 Sent Ben up to Saint ( ) coast and deed that land to him

206 and 个freed him. And made notes (some of them notes) on a page,

207 you under个stand. And freed him (on the 个ôther page) and sent him

208 back $\uparrow h o m e .^{\text {vi }}$

This extract contains the first part of the complicating action of this part of the story, which is again narrated by means of a long constructed dialogue, this time between Uncle Ben and his owner, Jefferson Davis. This story is really performed (cf Bangerter, Mayor \& Pekarek Doehler, 2011, p.199), as the introductory repetitive tapping of the interviewee's cane mimicking the protagonist's knocking on Jefferson Davis' door, the interviewee's marked prosody, and changes in volume during the quoted speech indicate. This story's main point is 
quite similar to the first embedded story, namely that the protagonist is an active, powerful agent in spite of his slave identity, and this main point is again talked into being, and thus demonstrated, by means of direct reported speech. An important point of this reported exchange is the construction of the slave's display of knowledge, which is closely connected to power (see e.g. Wodak, 2009, p.45 and following). The performance of the differing distribution of knowledge between the interlocutors in this reported exchange thus enacts the powerful position of the slave. The latter is presented as superior in many ways, even in comparison with the identity of slave master, embodied here by the character of Jefferson Davis. This is a crucial element of the story, since Davis is not only hierarchically superior (as the inequality of terms of address in this extract also illustrates), but he is also constructed in the interview as generally admired in the paragraphs preceding this story (see Van De Mieroop \& Clifton, 2012). In spite of these characteristics, the protagonist surpasses Jefferson Davis both intellectually, since the latter needs an explicit explanation before understanding the former's plan (lines 199-204), and discursively, which of course enforces the construction of a powerful status for this protagonist in spite of his identity of slave.

The protagonist's discursive supremacy is talked into being by means of several elements. First of all, the introductory small talk is initiated by Davis (lines 190-191) but is then quickly terminated by Ben in the following reported turn, in which the contrastive conjunction but signals the transition to goal oriented talk. As such, Ben is constructed as leading the conversation in the desired direction. Secondly, Ben's turns are prosodically more marked than those of Davis since the former's speaking volume is frequently louder and the pronunciation often receives more emphasis. Thirdly, Ben is explicitly telling his master what to do, thus not framing his plan as a request, but rather as an instruction. Ben's turns are framed as statements containing commands foregrounding himself as the agent (line 197 and 198: I want you to), asserting future tenses (line 201-202) and compelling imperatives (line 
203), in which even the respectful term of address master Jeff is abandoned and the informal address form man is used (line 203). Fourthly, Ben clearly does argument by opposing his master's dispreferred reply (line 199) to his proposal, even though the master accounts for this reply in the subsequent lines by accessing a master narrative of chattel slavery in which the land and Ben is constructed as property. However, Ben opposes this action with a turn that does opposition (Hutchby, 1996) and so, at a sequential level, he is resisting the actions of his master and at the same time arguing with him, which results in the slave winning the argument. Through these linguistic choices, a specific kind of social relationship between the characters in the storyworld is enacted, namely that Ben is discursively constructed as the most powerful interlocutor and thus not as a dominated slave but as a dominating freeman operating on equal footing with his master. Finally, the protagonist's powerful position in the reported conversation is also supported by the interviewee's only paralinguistic description in the extract. This description directly precedes Jefferson Davis' agreement with the plan and he is described as holding his head down (line 204), which could be viewed either as a display of inferiority, or as a display of resignation on the master's part to having no choice but to agree to the plan proposed by the slave. So, as the final lines of this extract demonstrate (lines 205-208), through the constructed dialogue, Davis is talked into being as a passive recipient of information that the slave obtained. Moreover he does not have any ideas of his own and he just carries out what he is instructed to do, in contrast to Ben who is constructed as 'smart Negro'. And although Davis is the agent of the action in these lines which are grammatically constructed as active sentences, his agency in these events is still mitigated because the subject is omitted in these phrases.

The slave's powerful position is further consolidated in the last part of the story, which consists of a final embedded story which describes the encounter with the Yankees. In this part of the story, a geographically based categorization is made explicit that was already 
introduced in the previous fragment, namely the opposition between the people from the North (line 194: those Yankees) versus the people from the South, thus joining the slaves and their slave owners in one group. As such, the hierarchical differences between them are being downplayed and similarity within the group is emphasized, which is of course in line with the slave's powerful discursive position as constructed through the direct reported speech. These two categories were already talked into being by means of the construction of an us-them opposition (Triandafyllidou \& Wodak, 2003; Leudar, Marsland \& Nekvapil, 2004) in lines 195-196 (our versus they) and this is further explored in the final fragment.

Extract 4 - part 3 (Johnson, turn by the interviewee)

208 And them Yankees got down to the Bend,

209 our home there. (.) The Yankees come, you understand.

210 They asked, 'Davis land? Is it Davis' farm?'

211 Say, 'Davis ain't got no land.' (.) 'Who land is here?'

212 >'It belongs to Ben Montgomery.' 'Where's Ben Montgomery?'

213 'There he is.'< Say, 'Come here, Ben.' (1.3)

214 >'This your land?' 'Yes, sir.' 'Where did you get that?'<(1.0)

215 'Bought it from my old master.' (2.9) He called ma-, called Misses.

216 He asked her to bring those papers, you understand. Show it to him. (.)

217 Read these notes and papers, you understand. (2.3)

$218 \cdot<\mathrm{A}::: \mathrm{h}$ ha, (.) that is your land. $>>$ Now I want white folk.

219 I don't (wa- want) no kind of Negro land.< (.) RIde on!'

$220>$ Ran across the road< (1.4) didn't bother the land at all.

221 And when (.) $\uparrow$ freedom time come back (1.7) master Jeff come on 
222 home, you understand. And he met them and £bhh- and

223 they gave him (cotton business) back and money£

From the first lines onwards, it is clear that the two parties are presented as oppositional, as clearly demonstrated by means of the demonstrative pronoun them preceding the term Yankees (line 208) as opposed to the first person plural possessive pronoun our preceding home (line 209), thus grouping the slaves with the land owners. Next to this, the story further illustrates the intellectual and discursive abilities of its protagonist, who is presented, after a brief introductory dialogue with unidentified interlocutors (lines 210-213), as the main interlocutor in the interaction with the Yankees. Furthermore, his essential role in this story of fooling the Yankees is further underlined by the fact that he is also presented as the agent of the actions (lines 215-216), while Jefferson Davis' wife (line 215: Misses) enacts a supporting role without a voice who follows the slave's instructions. Jefferson Davis only appears in the coda of this story, in which he is mainly constructed as the passive recipient of his properties (line 223).

Again, this story is characterized by a number of performance devices mimicking 'real life', as such presenting 'the reported utterances as accurate in several ways, not only in what was said but also in how it was said" (Haakana, 2007, p.159). The change in speed of delivery, in lines $218-219$, is especially interesting in this respect, since the first part's slow pace, which mimics the Yankee reading the papers, is highly contrastive with the second part which is spoken more rapidly. Then after a brief break, the increased volume of the imperative Ride on! (line 219) shows the moment the Yankee leader is fooled by the scam and instructs his men to leave ${ }^{\mathrm{vii}}$. By almost playing out the story and by means of the many understanding checks (you understand in lines 209, 216, 217 and 222), audience involvement in the story world is further ensured. 
So at the first level of positioning, this story is thus an illustration of the performance of a slave's superiority, not only towards his slave owners, but also towards the Yankees, and this is constructed throughout the direct reported speech sequences in which the slave is presented as discursively 'in power' and superior regarding his intellectual abilities and his access to knowledge. Thus on the one hand, this story can be read as an illustration of supremacy in spite of the protagonist's slave identity, but on the other hand, it also has another side to it, since by outsmarting the Yankees, the protagonist contributed to the preservation of the slave owner's land and thus also to economic inequality based on race. As such, it is quite a dual story that mostly underlines the complexity of the situation in which power is constructed as discursively negotiable. This is so despite the fact that power was structurally strictly pre-defined in the slave system and this is also talked into being throughout the story since many of the significant actions still need to be performed by the slave owners (i.e. extract 4 - part 1: the mistress needs to give the slave permission to leave;

extract 4 - part 2: the master needs to sign the land over to the slave). In its local interviewing context, this story functions as an aligning response conforming to the interviewer's request to tell this particular, obviously well-known, story, and the reported exchanges serve to add veracity, but also liveliness, to the interviewee's words.

\section{CONCLUSIONS}

Following Fairclough (1989, p.43), there are two kinds of power: power in discourse and power behind discourse. Both gain their potency from their hidden nature which lies in the naturalization of these forms of power as the enactment of ideology in which the subject position that is allotted by the dominant group to the dominated group is accepted, or at least acquiesced to. At one level, power in discourse, this can be seen in the sequential construction 
of discursive rights in reported exchanges attributed to the identities slave and master. And at the macro-level, this can be seen by the discourses (or master narratives) that are employed by the interviewees and which position the protagonists in the storyworld in asymmetrical positions with differing access to discursive rights, thus constructing the enactment of power within discourse in the storyworld. Moreover, in this way the micro is reflexively linked to the macro since each constructed dialogue in the storyworld relies on a master narrative that reflexively positions the protagonists in subject positions which in turn creates hegemonic access to discourse resources. In extracts 1, 2 and 3, we thus see how the reported speech of the protagonists enacts asymmetrical access to discursive resources which allows the master to dominate the interaction. No resistance is offered and these power imbalances are coconstructed by the acquiescence (willingly or unwillingly) of the slaves. This mobilizes a master narrative of chattel slavery in which slaves were seen as the property of their masters and as such had no rights (cf Van De Mieroop \& Clifton, 2011) and so potentially supports a discourse of white supremacy that underpinned the slave system in which, as explained by a contemporary apologist for the slave system:

"The status of the negro in American society - the social relation of the negro to the white man - which being in accord with the natural relations of the races, spring spontaneously from the necessities of human society; the white citizen is superior, the negro inferior; and therefore, wherever they happen to be in juxtaposition, the human law should accord, as it does in the South, with these relations thus inherent in their organizations, and thus fixed forever by the hand of God.” (Van Evrie, 1868, p.17)

However, to mobilize this master narrative does not necessarily entail setting up a position of acquiescence to it, as extract 1 has demonstrated. We have shown that even fragments that invoke the hegemonic power relations in quite similar ways, can function quite differently in their local interactional context. 
Alternatively, and to paraphrase Fairclough (Fairclough, 2001, p.124), since hegemony is, to a greater or less extent, always contested, it is not a closed system that dictates per se the discursive rights of protagonists but hegemonic power relations are necessarily put at risk by what happens in actual interactions. This is because constraints are not imposed upon the subjects from outside discourse, rather because of its performative nature, power is a process that is versatile and transient (Butler, 1990). Consequently, despite the repetition, widespread use, and privileged position of certain discourses that are informed, and given authority, by a history of prior interaction, every time that people talk (or that their speech is reported) power asymmetries are performed, yet they can always be enacted differently and so can challenge the status quo of more accepted discourses. As Wodak states:

"language indexes power, expresses power, is involved where there is contention over and a challenge to power. Power does not derive from language, but language can be used to challenge power, to subvert it, to alter distributions of power in the short and long term" (Wodak, 2001, p.11)

Therefore, in extract 4 , we see that a slave is constructed as being able to exert power over his hierarchical superiors. At a sequential level, this slave has greater rights and with these rights he reflexively draws on the master narrative of the smart Negro outwitting the dumb Yankees and the smart Negro finding a solution to his master's problems. Integral to this performance of power is positioning through which identities are constituted in talk. This is because if one is positioned as a slave within the operation of a master narrative of chattel slavery, then reflexively the slave has fewer discursive rights and thus is in an asymmetrical position in relation to the master. Conversely, since "texts are often sites of social struggle" (Reisigl \& Wodak, 2009, p.89), if one is positioned as a 'clever nigger', the protagonist in the storyworld claims discursive rights unavailable to the identity of a slave and so is able to use these to achieve discursive ascendancy over his superiors. However, despite positioning himself as the 
'clever nigger' in the story world, he does this not to outwit the whites but, drawing on an usand-them dichotomy (Leudar et al., 2004) that typically highlights the similarities within the ingroup (Triandafyllidou \& Wodak, 2003, p.213), the slave positions himself as a savior of his master against the invading northern Yankees and so draws on a master narrative not of resistance to the slave system but of the benevolent master (cf Van De Mieroop \& Clifton, 2012) whom he helps to trick the Yankees and so wittingly supports the plantation system. So, paradoxically, whilst within discourse, the slave exerts power over white protagonists he does not use this “emancipatory potential” (Flores Farfán \& Holzscheiter, 2010, p.141) to challenge the plantation system, but rather to support the South in its struggle against the abolitionist Yankee North. This story thus illustrates the extent to which hegemonic power, as the "'spontaneous' consent given by the great masses of the population to the general direction imposed on social life by the dominant fundamental group"(Gramsci, 1971, p.12), takes root in the consciousness of the slave who supports a system that acts against his group's interest by treating Negroes as inferior to their white owners, despite the latters' possible benevolence.

More specifically, in relation to reported speech, we aimed to demonstrate that through reported exchanges, narrators can do more than suggesting veracity, providing evidence for their assertions, and creating story involvement by their listeners. We argue that by making the audience a witness to the construction of dialogues through which characters position themselves vis-à-vis each other in the referential world and enact specific social relationships between these characters, listeners are offered direct access to the power relations that the narrator chooses to talk into being by means of the sequential characteristics and specific formulations of these dialogues. By offering the recipients a view into the turn distribution and the way in which these turns are shaped and formulated, a vivid image of the constructed discursive rights of the pro- and antagonists of the story is sketched. As such, the 
characteristics of these reported exchanges show the audience the performance of power relations as they are discursively constructed in front of them.

By presenting examples of the discursive construction of both hegemonic and nonhegemonic enactments of power relations through direct reported speech sequences (extracts 1-3 versus extract 4), we linked the micro to the macro-context and we also highlighted the non-essentialist nature of these power relations and the versatile functions of these sequences within their interactional contexts. As the second part of the analyses demonstrated, the slave may be constructed as the interlocutor who performs power in a particular situation through the discursive characteristics of the reported exchanges. But also in the first part of the analyses, in which the default power asymmetry of the slave system is discursively enacted in the constructed dialogues, the extracts highlight different sides of these power relations, thus contributing to the construction of a specific position for the narrators in the ongoing interactions. As such, direct reported speech forms a powerful persuasive device in conveying information about the power relations that are constructed on a turn-by-turn basis between the characters in the referential world and this may confirm or disconfirm the typical discursive rights that they normatively hold, thus underlining the non-essentialist and negotiated nature of identities (whether in reported speech or elsewhere).

Importantly, we do not claim that constructed dialogues necessarily reflect the 'actual' power relations as they 'existed' in the past. This is on the one hand self-evident, given the fact that direct reported speech has generally been described as an inaccurate rendition of previous utterances, if these occurred at all (cf Tannen, 1989). This is especially realistic in this case given the time lapse of more than seventy years between the narrated events and the interview which makes a literal repetition of a previous utterance highly unlikely. On the other hand, it is also a crucial characteristic of narratives that they are regarded as performances related to their contemporary contexts, rather than perfect reflections of the 
past. Again, this is particularly relevant for this corpus, since the importance of looking at what these direct reported speech sequences do within the interviewing context and how they contribute to the message that is conveyed through these stories to the audience cannot be overemphasized. For this, we drew on Bamberg's model of positioning, and as Bamberg (1997a) notes, positioning is a process and findings regarding the first level of positioning, have implications for the other levels of positioning as well. In this case, the enactment of social relationships between characters on a content plane constructs the other interlocutors in the interview world (interviewers, but also other interviewees as in extract 1) as observers of how the slaves and their masters interacted and what power relationships were performed as such. Furthermore, the stories in which these reported exchanges occur, serve many different functions at the second level of positioning, ranging from complying with the interviewer's request to tell a particular story (extract 4) to countering another interviewee's response and thus refuting her opinion (extract 1). In turn, we have demonstrated that this has implications regarding the way the interviewees position themselves vis-à-vis the master narratives of racial inequality present both in the slave system and the institutionalized racial segregation of the 1940s. The reported exchanges in these stories all help to increase veracity and liveliness, as has been demonstrated extensively in previous studies (see e.g. Holt, 1996; Buttny, 1997; Schiffrin, 2003). Our particular focus on reported exchanges, instead of short stretches of reported speech as is often the case, has highlighted that power relations can be really enacted on the content plane and this can be made visible by looking at the constructed sequentiality of these reported exchanges and the discourse strategies that are used in them. 


\section{REFERENCES}

Álvarez-Cáccamo, C. (1996). The power of reflexive language(s): Code displacement in reported speech. Journal of Pragmatics, 25(1), 33-59.

Atkinson, P. \& Delamont, S. (2006). Rescuing narrative from qualitative research. Narrative Inquiry, 16(1), 164-172.

Bakhtin, M. (1981). The Dialogic Imagination (translated by M. Holquist and C. Emerson). Austin: University of Texas Press.

Bamberg, M. (1997a). Language, concepts and emotions: the role of language in the construction of emotions. Language sciences, 19(4), 309-340.

Bamberg, M. (1997b). Positioning between structure and performance. Journal of Narrative and Life History, 7, 335-342.

Bamberg, M. (2003). "Positioning with Davie Hogan - Stories, Tellings, and Identities. In C. Daiute \& C. Lightfoot (Eds.), Narrative analysis: Studying the development of individuals in society (pp. 135-157). London: Sage.

Bamberg, M. (2006). Stories: Big or small; Why do we care? Narrative Inquiry, 16(1), 139147.

Bamberg, M. (2010). Who am I? Narrative and its contribution to self and identity. Theory and Psychology, 21(1), 1-22.

Bamberg, M., De Fina, A. \& Schiffrin, D. (2011). Discourse and identity construction. In S. Schwartz, K. Luyckx \& V. Vignoles (Eds.), Handbook of identity theory and research (pp. 177-199). Berlin/New York: Springer Verlag.

Banfield, A. (1973). Narrative style and the grammar of direct and indirect speech. Foundations of Language, 10(1), 1-39. 
Bangerter, A., Mayor, E. \& Pekarek Doehler, S. (2011). Reported Speech in Conversational Storytelling During Nursing Shift Handover Meetings. Discourse Processes, 48(3), $183-214$.

Bauman, R. \& Briggs, C. (1992). Genre, Intertextuality, and Social power. Journal of Linguistic Anthropology, 2(2), 131-172.

Baxter, J. (2009). The language of female leadership. London: Palgrave Macmillan.

Benwell, B. \& Stokoe, E. (2006). Discourse and identity. Edinburgh: Edinburgh University Press.

Blassingame, J.W. (1975). Using the Testimony of Ex-Slaves: Approaches and Problems. The Journal of Southern History, 41(4), 473-492.

Brown, P. \& Levinson, S.C. (1987). Politeness, some universals in language usage. Cambridge University Press: Cambridge.

Butler, J. (1990). Gender Trouble. Feminism and the Subversion of Identity. New York: Routledge.

Buttny, R. (1997). Reported Speech in Talking Race on Campus. Human Communication Research, 23(4), 477-506.

Buttny, R. \& Cohen, J.R. (2007). Drawing on the words of others at public hearings: Zoning, Wal-Mart, and the threat to the aquifer. Language in Society, 36(5), 735-756.

Buttny, R. \& Williams, P.L. (2000). Demanding Respect: The Uses of Reported Speech in Discursive Constructions of Interracial Contact. Discourse \& Society, 11(1), 109-133. Clayman, S.E. (1992). Footing in the achievement of neutrality: the case of news-interview discourse. In P. Drew \& J. Heritage (Eds.), Talk at work - Interaction in institutional settings (Studies in Interactional Sociolinguistics 8) (pp. 163-198). Cambridge University Press: Cambridge. 
Clayman, S.E. (2007). Speaking on behalf of the public in broadcast news interviews. In E. Holt \& R. Clift (Eds.), Reporting Talk: Reported Speech in Interaction (pp. 221-243). Cambridge: Cambridge University Press.

Clift, R. \& Holt, E. (2007). Introduction. In E. Holt \& R. Clift (Eds.), Reporting Talk; Reported speech in interaction (pp. 1-15). Cambridge: Cambridge University Press. De Fina, A. (2006). Group identity, narrative and self-presentations. In A. De Fina, D. Schiffrin \& M. Bamberg (Eds.), Discourse and Identity, Studies in Interactional Sociolinguistics 23 (pp. 351-375). Cambridge University Press: Cambridge.

De Fina, A. (2009). Narratives in interview - The case of accounts; For an interactional approach to narrative genres. Narrative Inquiry, 19 (2), 233-258.

De Fina, A. (2011). Researcher and informant roles in narrative interactions: Constructions of belonging and foreign-ness. Language in Society, 40, 27-38.

Dowding, K. (2006). Three-dimensional power: A discussion of Steven Lukes' Power: A radical view. Political Studies Review, 4, 136-145.

Drew, P. (1998). Complaints about transgressions and misconduct. Research on Language and Social Interaction, 31(3/4), 295-325.

Escott, P.D. (1991). The Art and Science of Reading WPA Slave Narratives. In C.T. Davis \& H.L.J. Gates (Eds.), The slave's narrative (pp. 40-47). New York: Oxford University Press.

Fairclough, N. (1989). Language and power. New York: Longman inc.

Fairclough, N. (2001). Critical discourse analysis as a method in social scientific research. In R. Wodak \& M. Meyer (Eds.), Methods of Critical Discourse Analysis (pp. 121-138). London: Sage. 
Flores Farfán, J.A. \& Holzscheiter, A. (2010). The power of discourse and the discourse of power. In R. Wodak, B. Johnstone \& P. Kerswill (Eds.), The Sage handbook of sociolinguistics (pp. 139-152). London: Sage.

Fox Tree, J.E. \& Tomlinson, J.M. (2008). The rise of like in spontaneous quotations. Discourse Processes, 45(1), 85-102.

Freeman, M. (2006). Life "on holiday"? In defense of big stories. Narrative Inquiry, 16(1), 131-138.

Georgakopoulou, A. (1995). Women, men, and conversational narrative performances: aspects of gender in Greek storytelling. Anthropological Linguistics, 37(4), 460-486.

Georgakopoulou, A. (2006). Thinking big with small stories in narrative and identity analysis. Narrative Inquiry, 16(1), 122-130.

Goffman, E. (1979). Footing. Semiotica, 25 (1/2), 1-29.

Gramsci, A. (1971). Selections from the Prison Notebooks of Antonio Gramsci. London: Lawrence Wishart.

Greasley, P. (1994). An investigation into the use of the particle well: Commentaries on a game of snooker. Journal of Pragmatics, 22(5), 477-494.

Haakana, M. (2007). Reported thought in complaint stories. In E. Holt \& R. Clift (Eds.), Reporting Talk: Reported Speech in Interaction (pp. 150-178). Cambridge: Cambridge University Press.

Heritage, J. (1984). Garfinkel and ethnomethodology. Cambridge: Polity Press.

Heritage, J. \& Sorjonen, M.-L. (1994). Constituting and Maintaining Activities across Sequences: and-prefacing as a Feature of Question Design. Language in Society, 23(1), 1-29.

Holmes, J., Stubbe, M. \& Vine, B. (1999). Construction professional identity: "Doing power" in policy units. In S. Sarangi \& C. Roberts (Eds.), Talk, work and institutional order; 
discourse in medical, mediation and management settings (pp. 351-385). Berlin - New York: Mouton de Gruyter.

Holstein, J.A. \& Gubrium, J.F. (2003). Active interviewing. In J.A. Holstein \& J.F. Gubrium (Eds.), Postmodern Interviewing (pp. 67-80). Thousand Oaks, CA: Sage.

Holt, E. (1996). Reporting on Talk: The Use of Direct Reported Speech in Conversation. Research on Language and Social Interaction, 29(3), 219-245.

Holt, E. (2000). Reporting and Reacting: Concurrent Responses to Reported Speech. Research on Language and Social Interaction, 33(4), 425-454.

Hutchby, I. (1996). Confrontation talk: Argument, asymmetries and power on talk radio. Hilldale, N.J: Erlbaum.

Hutchby, I. (1999). Beyond Agnosticism?: Conversation Analysis and the Sociological Agenda. Research on Language and Social Interaction, 32, 85-93.

Hutchby, I. \& Wooffitt, R. (1998). Conversation analysis: Principles, practices and applications. Cambridge: Polity Press.

Jäger, S. (2001). Discourse and knowledge. Theoretical and methodological aspects of critical discourse and dispositive analysis. In R. Wodak \& M. Meyer (Eds.), Methods of Critical Discourse Analysis (pp. 32-63). London: Sage.

Jefferson, G. (2004). Glossary of transcript symbols with an introduction. In G.H. Lerner (Ed.), Conversation Analysis; Studies from the first generation (pp. 13-31). Amsterdam/Philadelphia: John Benjamins.

Kitzinger, C. (2000). Doing feminist conversation analysis. Feminism and Psychology, 10, 163-193.

Labov, W. \& Waletzky, J. (1966). Narrative Analysis: oral versions of personal experience. In J. Helm (Ed.), Essays on the Verbal and Visual Arts (pp. 12-44). Universiy of Washington Press: Seattle. 
Leudar, I., Marsland, V. \& Nekvapil, J. (2004). On membership categorization: 'us', 'them' and 'doing violence' in political discourse. Discourse \& Society, 15(2-3), 243-266.

Library of Congress (2011). Voices from the Days of Slavery; Former Slaves Tell Their Stories. Retrieved from http://memory.loc.gov/ammem/collections/voices/index.html.

Litosseliti, L. (2006). Constructing gender in Public arguments: The female voice as emotional voice. In J. Baxter (Ed.), Speaking Out. The female voice in Public context (pp. 40-60). Basingstoke: Palgrave Macmillan.

Lomax, A. (1993). The Land Where the Blues Began. New York: Pantheon Books.

Lukes, S. (1974). Power: a radical view. London / New York: Macmillan.

Mathis, T. \& Yule, G. (1994). Zero quotatives. Discourse Processes, 18, 63-76.

Matoesian, G.M. (1993). Reproducing Rape: Domination through Talk in the Courtroom. Chicago: University of Chicago Press.

Moita-Lopes, L.P. (2006). On being white, heterosexual and male in a Brazilian school:multiple positionings in oral narratives. In A. De Fina, D. Schiffrin \& M. Bamberg (Eds.), Discourse and Identity, Studies in Interactional Sociolinguistics 23 (pp. 288-313). Cambridge University Press: Cambridge.

Muntigl, P. (2004a). Ontogenesis in Narrative Therapy: A Linguistic-Semiotic Examination of Client Change. Family Process, 43(1), 109-131.

Muntigl, P. (2004b). Narrative Counselling: Social and linguistic processes of change. Amsterdam/Philadelphia: John Benjamins.

Neville, M. (2006). Making sequentiality salient:and-prefacing in the talk of airline pilots. Discourse Studies, 8(2), 309-332.

Norrick, N.R. (1998). Retelling stories in spontaneous conversation. Discourse Processes, 25(1), 75-97. 
Norrick, N.R. (2003). Remembering and forgetfulness in conversational narrative. Discourse Processes, 36(1), 47-76.

Reisigl, M. \& Wodak, R. (2009). The Discourse-Historical Approach (DHA). In R. Wodak \& M. Meyer (Eds.), Methods for Critical Discourse Analysis (pp. 87-121). London: Sage.

Schiffrin, D. (1987). Discourse Markers. Cambridge University Press: Cambridge.

Schiffrin, D. (2003). We knew that's it: retelling the turning point of a narrative. Discourse Studies, 5(4), 535-561.

Semino, E., Short, M. \& Culpeper, J. (1997). Using a corpus to test a model of speech and thought presentation. Poetics, 25, 17-43.

Soapes, T.F. (1977). The Federal Writers' Project Slave Interviews: Useful Data or Misleading Source. The Oral History Review, 5, 33-38.

Stivers, T. (2005). Modified Repeats: One Method for Asserting Primary Rights From Second Position. Research on Language and Social Interaction, 38(2), 131-158.

Stokoe, E. \& Edwards, D. (2007). 'Black this, black that': racial insults and reported speech in neighbour complaints and police interrogations. Discourse \& Society, 18(3), 337-372.

Tannen, D. (1989). Talking Voices, Repetition, dialogue, and imagery in conversational discourse. Cambridge: Cambridge University Press.

ten Have, P. (1991). Talk and institution: a reconsideration of the 'asymmetry' of doctorpatient interaction. In D. Boden \& D.H. Zimmerman (Eds.), Talk and social structure: studies in ethnomethodology and conversation analysis (pp. 138-163). Cambridge: Polity Press.

Triandafyllidou, A. \& Wodak, R. (2003). Conceptual and methodological questions in the study of collective identities: An introduction. Journal of Language and Politics, 2(2), 205-223. 
Van De Mieroop, D. \& Clifton, J. (2011). Standardized relational pairs in interviews with former slaves: construction, negotiation and alignment. Narrative Inquiry, 21(1), 4467.

Van De Mieroop, D. \& Clifton, J. (2012). The interactional negotiation of group membership and ethnicity; The case of an interview with a former slave. Discourse \& Society, 23(2), 163-183.

Van Dijk, T.A. (2009). Society and Discourse, How Social Contexts Influence Text and Talk. Cambridge: Cambridge University Press.

Van Evrie, J. (1868). White supremacy and Negro subordination; or, Negroes a subordinate race, and (so-called) slavery its normal condition. New York: Van Evrie, Horton and Co.

Vann Woodward, C. (1991). History from Slave Sources. In C.T. Davis \& H.L.J. Gates (Eds.), The slave's narrative (pp. 48-59). New York: Oxford University Press.

Vološinov, V.N. (1973). Marxism and the Philosophy of Language. New York: Seminar Press.

Whooley, O. (2006). The political work of narratives; A dialogic analysis of two slave narratives. Narrative Inquiry, 16(2), 295-318.

Wodak, R. (2001). What CDA is about - a summary of its history, important concepts and its developments. In R. Wodak \& M. Meyer (Eds.), Methods of Critical Discourse Analysis (pp. London: Sage.

Wodak, R. (2009). The Discourse of Politics in Action, Politics as Usual. London: Palgrave Macmillan.

Wodak, R. \& Weiss, G. (2005). Analyzing European Union discourses: Theories and applications. In R. Wodak \& P. Chilton (Eds.), A New Agenda in (Critical) Discourse 
Analysis: Theory, methodology and interdisciplinarity (pp. 121-135).

Amsterdam/Philadelphia: John Benjamins.

Wooffit, R. (2007). The dead in the service of the living. In E. Holt \& R. Clift (Eds.),

Reporting Talk: Reported Speech in Interaction (pp. 244-269). Cambridge: Cambridge University Press.

Yetman, N.R. (1967). The background of the slave narrative collection. American Quarterly, 19(3), 534-553.

\section{NOTES}

${ }^{i}$ As part of the New Deal, the Works Progress Administration (WPA) sponsored a Federal Writers Project which put out of work writers to work collecting narratives of American life, including many interviews with ex-slaves.

ii For the same reason, we do not go into a discussion of some of the dialectal features typical of AAVE that occur in these fragments.

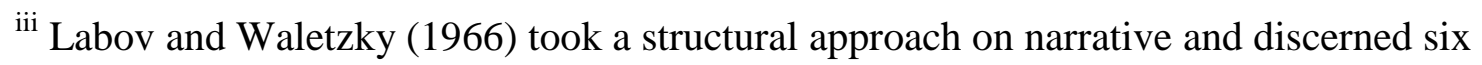
elements that could (but do not always) occur in a typical narrative, namely:

- abstract (a summary of the upcoming story),

- orientation (a section orienting the listener in respect to person, place, time, and behavioral situation),

- complicating action (the main body of narrative clauses which usually comprises a series of events),

- resolution (the result of these events),

- coda (a device for returning the verbal perspective to the present moment),

- evaluation (the point of the story). 
${ }^{\text {iv }}$ Names are often not reproduced because they are usually hardly intelligible and thus they are very likely to elicit mistakes.

${ }^{\mathrm{v}}$ There is an alternative interpretation of this fragment possible, which would highlight the unexpected nature of the Yankees' departure and which would frame the slave owner's reported talk as a necessary commentary because of this unexpectedness. The presence of the discourse marker well (line 383) can also be read as supporting this interpretation, since this has been described as a typical marker of unexpectedness as well, as Greasley (1994) observed in the context of snooker games. In this interpretation, the slave owner's reported talk would thus be a new first turn which initiates an interaction that could possibly occur sometime after the completed question-answer exchange between the storyteller and the mother. In this case, the slave master would be performing his first turn rights much in the same way as in extract 1.

${ }^{v i}$ The rest of this line is omitted here. It is presented at the beginning of the next extract.

${ }^{\text {vii }}$ It is unfortunate that there is no video data available, since it is highly likely that these performance features are supported by gestures, but given the age of the data that is of course quite understandable. 